\title{
Ruxandra Ana
}

ruxandra.ana@gmail.com

Instytut Etnologii i Antropologii Kulturowej

Uniwersytet Warszawski

\section{A LO CUBANO: UTOWAROWIENIE TAŃCA I REPREZENTACJE KUBAŃSKOŚCI W KONTEKŚCIE TURYSTYKI KULTUROWEJ}

\section{A Lo Cubano: Commodification of dance and representations of Cubanness in the context of cultural tourism}

Streszczenie: Artykuł analizuje sposoby, w jakie, w warunkach dynamicznych przemian zachodzących na Kubie, niematerialne dziedzictwo kulturowe staje się podstawowym zasobem generującym dochód, zanurzonym w skomplikowanych sieciach wyobrażeń i reprezentacji kreowanych przez przemysł turystyczny. W związku ze wzrostem znaczenia turystyki opartej na doświadczeniu (experiential tourism; patrz: Salazar 2011), praktyki cielesne (w tym taniec) są kluczowe nie tylko dla instytucji zajmujących się ochroną i promocją dziedzictwa kulturowego, ale również w przypadku małych przedsiębiorstw stanowiących dla Kubańczyków alternatywne źródła dochodu poza sektorem państwowym. Szkoły tańca zajmujących się nauczaniem tańca zagranicznych turystów oraz rosnąca popularność tańców kubańskich poza wyspą pokazują, w jaki sposób następuje przyswajanie i adaptacja niektórych turystycznych wyobrażeń w lokalnej narracji o kubańskości (lo cubano) oraz jak ciała nabierają walorów transakcyjnych. Realia gospodarcze i nierówności społeczne wynikające z kontaktów z obcokrajowcami skutkują twórczym podejściem do zysków, utrwalając jednocześnie oczekiwania i fantazje dotyczące Kuby. Niejednokrotnie zjawisko to jest silnie naznaczone rasowo, jako że wielu ciemnoskórych Kubańczyków, bez dostępu do legalnych miejsc pracy w branży turystycznej, może wykorzystać pozory „rasowej autentyczności” w przestrzeniach związanych z tańcem na swoją korzyść. Artykuł 
opiera się na materiałach zgromadzonych w trakcie kilkumiesięcznych badań terenowych prowadzonych w Hawanie w latach 2015-2016 oraz w okresie marzec - maj 2018 wśród profesjonalnych tancerzy, instruktorów i właścicieli szkół tańca.

Słowa kluczowe: Kuba, dziedzictwo niematerialne, taniec, przedsiębiorczość, turystyka.

Abstract: The article looks at the intangible cultural heritage and its importance as a resource that creates economic revenue in the context of rapid transformations currently taking place in Cuba, and integrated in a complex network of tourism imaginaries and representations. Given the increased demand for "experiential tourism" (Salazar 2011), dance practices become central not only to institutions in charge of safeguarding and promoting heritage, but also to emerging small businesses as alternative forms of revenue outside the state sector. Dance schools aimed at foreign tourists, and the increased popularity of Cuban dance genres outside Cuba, indicate how parts of the tourist imaginary are adopted and adapted in Cuban narratives about Cubanness, and how bodies become transactional in more than one way. Economic realities and social inequalities that stem from contact with foreigners result in creative approaches for financial gain, perpetuating expectations about Cuban fantasies. The phenomenon is often racially marked, as many of the darker skinned Cubans, with no access to legal jobs in the tourist industry, seem to be capable of exploiting the appearance of 'authenticity' in dance spaces commonly associated with blackness. The article is based on the findings of long term fieldwork conducted in Havana in 2015 and 2016 and from March to May 2018 among professional dancers, instructors and dance school owners.

Keywords: Cuba, intangible heritage, dance, entrepreneurship, tourism. 
A lo cubano: utowarowienie tańca i reprezentacje kubańskości...

Kierowca taksówki, który odebrał mnie z lotniska w Hawanie, okazał się, jak zresztą większość jego kolegów po fachu, bardzo rozmowny. Zapytał oczywiście o długość mojego pobytu na Kubie, a kiedy powiedziałam, że spędzę tu siedem miesięcy, chciał wiedzieć, czy mój mąż lub chłopak jest Kubańczykiem. Kiedy zaprzeczyłam, padł następujący komentarz: „Zawsze mówię moim klientom, że jeśli znajdą Kubańczyka lub Kubankę, w których się zakochają, pokochają również Kubę i będą chcieli wracaćc". Następnie rozmowa potoczyła się w kierunku sezonu turystycznego (najwięcej turystów przyjeżdża na Kubę w okresie od listopada do marca), pogody, dostępu do Internetu na wyspie oraz nowo powstałych i najlepszych sklepów z żywnością. Gdy zbliżaliśmy się do mojego domu, podał mi wizytówkę i wymienił nazwę jednego z najbardziej znanych klubów tanecznych w mieście. „Jeśli miałabyś kiedyś ochotę pójść potańczyć, jestem do dyspozycji. My, Kubańczycy, tacy jesteśmy: lubimy tańczyć, lubimy imprezować. To jest świetne miejsce: można tam potańczyć, ale też poznać nowych ludzi". Takie zachowanie taksówkarza zupełnie mnie nie zaskoczyło. Osiem lat podróży na Kubę nauczyło mnie, że taniec może być świetnym początkiem różnych rozmów. Temat ten pojawia się równie często jak sugestia, że turystki powinny znaleźć na Kubie chłopaka, aby w pełni cieszyć się wszystkim, co wyspa ma do zaoferowania.

\section{Wprowadzenie}

W niniejszym artykule analizuję sposoby, w jakie niematerialne dziedzictwo kulturowe, zanurzone w skomplikowane sieci wyobrażeń i reprezentacji kreowanych przez przemysł turystyczny w procesie utowarowiania kultury, staje się podstawowym zasobem generującym dochód w warunkach dynamicznych przemian zachodzących na Kubie w okresie późnego socjalizmu (Yurchak 2005).

W związku ze wzrostem znaczenia turystyki opartej na doświadczeniu (experiential tourism, Salazar 2011) pewne elementy kubańskiego dziedzictwa kulturowego zaczęły w ostatnich dwóch dekadach odgrywać pierwszoplanową rolę w rozwoju sektora turystycznego. Praktyki cielesne (w tym taniec) zajmują obecnie kluczową pozycję nie tylko w działaniach instytucji zajmujących się ochroną i promocją dziedzictwa kulturowego, lecz również jako alternatywne źródła dochodu poza sektorem państwowym. Tym samym kultura staje się „wartościowa” w sposób wymierny, 
ekonomiczny, a zagadnienia związane z tożsamością stają się interesujące nie tylko jako abstrakcyjne koncepcje, lecz także, przynajmniej częściowo, jako działania służące sektorowi gospodarczemu: turystyce i dziedzictwu (Kirshenblatt-Gimblett 1998, Yudice 2003).

Analizę utowarowienia niematerialnego dziedzictwa skoncentruję wokół dwóch najbardziej popularnych i kojarzonych z Kubą form tanecznych. W pierwszej kolejności analizuję salsę kubańską (casino), jako wyraz wyobrażonej kubańskości, najbardziej popularny taniec kubański za granicą, a także najistotniejszy dla rozwoju małych prywatnych szkół tańca, pojawiających się w ostatnich latach na wyspie. W drugiej kolejności przyglądam się rumbie, która podlega oficjalnej ochronie (wpisana na listę UNESCO) jako wyraz kultury afro-kubańskiej. Lekcje rumby są poszukiwane przez miłośników tańca jako szczególne potwierdzenie ich umiejętności, jako ,powrót do korzeni” autentycznych form tanecznych (w przeciwieństwie do salsy, postrzeganej jako bardziej komercyjna). Oba gatunki są przykładem trwającego procesu utowarowienia kultury i chociaż sposoby, w jakie są prezentowane zagranicznym odbiorcom, wykazują pewne cechy wspólne, każdy z nich charakteryzuje się specyficzną dynamiką i ujawnia różne, ale komplementarne wyobrażenia na temat wyspy i jej mieszkańców.

Artykuł powstał na podstawie materiałów zgromadzonych w trakcie badań terenowych prowadzonych w Hawanie w latach 2015-2016 (cztery miesięczne wyjazdy) oraz w okresie marzec - maj 2018 roku ${ }^{1}$ wśród profesjonalnych tancerzy, instruktorów i właścicieli szkół tańca. Sięgam również do materiałów etnograficznych zebranych przeze mnie w latach 2011-2014 podczas badań procesów patrymonializacji kubańskiej rumby (Ana 2017a). Badania były prowadzone metodą etnograficzną: bazowały na długotrwałej obserwacji uczestniczącej wśród różnych grup pośrednio i bezpośrednio zaangażowanych w tworzenie, rozwój i komercjalizację dziedzictwa kulturowego związanego z tańcem na użytek turystyki kulturowej. Ważnym elementem etnografii był też ucieleśniony aspekt tańca, wynikający z mojego wieloletniego doświadczenia tanecznego. W Hawanie uczestniczyłam zarówno w indywidualnych lekcjach tańca (salsa kubańska/casino, rumba, technika tańca kubańskiego), jak i w warsztatach oraz lekcjach grupowych dla turystów zagranicznych, a także w treningach

${ }^{1}$ Publikacja jest efektem realizacji badań w ramach projektu finansowanego przez Narodowe Centrum Nauki, nr rejestracyjny 2017/25/N/HS3/00315. 
A lo cubano: utowarowienie tańca i reprezentacje kubańskości...

zawodowych tancerzy. Obserwację uczestnicząca i praktykę taneczną uzupełniły nieustrukturyzowane i częściowo ustrukturyzowane wywiady $\mathrm{z}$ elementami wywiadu biograficznego ${ }^{2}$ przeprowadzone $\mathrm{z}$ instruktorami tańca, z profesjonalnymi tancerzami, właścicielami szkół tańca oraz turystami i właścicielami biur podróży.

\section{Turystyka kulturowa i wizja kraju ,zatrzymanego w czasie”}

Upadek bloku sowieckiego w 1991 r. spowodował wiele radykalnych zmian społecznych i gospodarczych na Kubie. Ówczesny przywódca Fidel Castro określił ten okres początku lat 90. jako „szczególny okres w czasach pokoju": kraj nie otrzymywał już pomocy od globalnej potęgi dostarczającej gaz i żywność w zamian za cukier, co spowodowało znaczny spadek dochodów kraju. Równocześnie zaostrzenie amerykańskiego embarga handlowego miało bezpośredni wpływ na codzienne życie mieszkańców, stojących wówczas w obliczu braku podstawowych produktów. Kubańczycy gwałtownie zubożeli i nieuniknione stało się wprowadzenie zmian w systemie politycznym i gospodarczym. W roku 1994 kraj został ponownie otwarty dla turystów, utworzono Ministerstwo Turystyki, a większość środków budżetowych została przeznaczona na renowację i odbudowę obiektów turystycznych. Biorąc pod uwagę szybki rozwój turystyki i niewystarczającą bazę hotelową, rząd zezwolił w 1997 r. na działalność małych firm wynajmujących pokoje dla zagranicznych gości szukających alternatywnego zakwaterowania (casas particulares).

Sektor turystyczny był od samego początku oddzielony od reszty gospodarki (Espino 1993)33. Wzrosły nierówności ekonomiczne, powodując coraz większe rozwarstwienie społeczne, które nałożyło się na istniejące na wyspie podziały rasowe ${ }^{4}$. Jednym z powodów tych nierówności było uzależnienie Kubańczyków od przekazów pieniężnych przesyłanych

2 Przeprowadziłam 23 wywiady w okresie 2011-2014, 9 wywiadów w okresie 2015-2016, 8 wywiadów w okresie marzec - maj 2018.

${ }^{3}$ Od momentu otwarcia się kraju na turystykę, na Kubie obowiązują równolegle dwie waluty: CUC (peso convertible / peso wymienialne) oraz CUP (moneda nacional / waluta narodowa). 1 CUC = 24 CUP = 1,14 EUR. Podwójny obieg walutowy to jeden z efektów wpływu turystyki na gospodarkę kubańską, który z kolei powoduje pogłębiające się różnice społeczne. W 2017 r. średnia pensja wynosiła 767 CUP (ok. 27 EUR) miesięcznie.

${ }^{4}$ Chociaż zgodnie z ideologią rewolucji, rasizm na Kubie nie istnieje - będąc atrybutem kapitalizmu, rasizm znika, gdy zostaje wyeliminowany przywilej klasowy 
przez krewnych, które są niezwykle ważne dla przeżycia i funkcjonowania wielu gospodarstw domowych. Migracja z Kuby była, i w dalszym ciągu jest, zjawiskiem typowym dla klasy średniej i wyższej, stąd więcej białych Kubańczyków otrzymuje przekazy pieniężne z zagranicy, podczas gdy Afro-Kubańczycy są zwykle pozbawieni takiej pomocy finansowej. Jednocześnie Afro-Kubańczycy żyją w gęsto zaludnionych dzielnicach Hawany, a zatem mają mniejsze szanse i możliwości prowadzenia własnej działalności gospodarczej, na przykład wynajmowania domów turystom lub otwierania restauracji. Badania Alejandro de la Fuente (1998) pokazują, że dyskryminacja rasowa na Kubie jest w dalszym ciągu wynikiem strukturalnego rasizmu, a nie tylko indywidualnych uprzedzeń. Osoby czarnoskóre są często wykluczone z sektora turystycznego jako niemające buena presencia (,dobrego wyglądu“), co zwykle oznacza niepożądany kolor skóry.

Kiedy w 2008 r. Fidel Castro ustąpił z pełnionej funkcji, kraj wkroczył w nowy etap reform gospodarczych. Powoli, lecz definitywnie przekształcały się stosunki między państwem, jednostką i społeczeństwem, a jednocześnie kraj nie zrezygnował do końca z modelu socjalistycznego. Prezydent Raul Castro zezwolił na prowadzenie działalności prywatnej i wprowadził reformy mające na celu ułatwienia dla tego sektora w postaci nowych zezwoleń na prowadzenie działalności gospodarczej. Praca na własny rachunek (cuentrapropismo) na Kubie nie tylko pozwoliła na przejście z sektora państwowego do sektora prywatnego, ale też spowodowała przekształcenie stosunków pracy i stała się symbolem przemian gospodarczych i politycznych. Drobni przedsiębiorcy są uważani za grupę, której działalność pozwala na przejście od socjalizmu do gospodarki wolnorynkowej (Phillips 2006).

W dniu 17 grudnia 2014r. przywódcy Kuby i Stanów Zjednoczonych, Raul Castro i Barack Obama, ogłosili wznowienie stosunków dyplomatycznych, zawieszone w $1961 \mathrm{r}$. Wydarzenie to stało się kamieniem milowym w stosunkach amerykańsko-kubańskich i przyniosło wiele zmian: ponowne ustanowienie ambasad w Hawanie i Waszyngtonie, złagodzenie sankcji w transakcjach finansowych na Kubie ${ }^{5}$, zniesienie części ograniczeń w podróżach między obydwoma krajami oraz ponowne rozważenie statusu Kuby jako kraju wspierającego terroryzm. Obwieszczenie to nie

${ }^{5}$ W 2014 r., zwiększono kwoty pieniędzy, które emigranci mogą przesłać swoim rodzinom pozostającym na wyspie. 
A lo cubano: utowarowienie tańca i reprezentacje kubańskości...

tylko zwróciło na kraj uwagę światowej opinii publicznej, ale także spowodowało szybki rozwój turystyki międzynarodowej: wzrost z 3,5 mln odwiedzających w 2015 r. do ponad $2 \mathrm{mln}$ w pierwszym półroczu 2016 r. ${ }^{6}$. Jednak odwilż w stosunkach między USA a jego karaibskim sąsiadem była krótkotrwała - prezydent Donald Trump ponownie wprowadził ograniczenia $\mathrm{w}$ handlu i w podróżowaniu na wyspę, powracając do bardziej restrykcyjnej polityki wobec Kuby.

Niemniej rozwój turystyki i związany z nią napływ kapitału zagranicznego przyczyniły się do zmiany tego, jak Kubańczycy postrzegają przyszłość, stworzyły perspektywę bogactwa i dobrobytu, wpłynęły też na postrzeganie i wykonywanie pracy. Jednocześnie doświadczenia turystyczne przedstawione w zachodnich mediach i w ofertach zagranicznych touroperatorów powiązane były z pewnym rodzajem nostalgii i poczuciem determinacji, aby „zobaczyć Kubę, nim się zmieni”. Wyspę zaczęto uważać za żywe muzeum historii, a efektem tego było utowarowienie wyobrażonej kubańskości; zjawisko wynikające z różnic klasowych i etnicznych, których nie można oddzielić od hierarchii genderowych i rasowych, mających bezpośrednie precedensy w kolonializmie (Stoler 1995).

Nostalgiczne przedstawienia „kraju zatrzymanego w czasie” połączone z wizerunkami przedrewolucyjnej ekstrawagancji kabaretów i elementami symboliki rewolucji kubańskiej stanowią żelazny zestaw atrakcji, przedstawiany przez większość przewodników turystycznych w programach zorganizowanych wycieczek i w ofertach lokalnych firm skierowanych do zagranicznych gości. Przekaz jest dodatkowo wzmocniony naturalizacją egzotyki i narracją o pogodzie ducha, zmysłowości i namiętności mieszkańców Karaibów. Turystyczne zainteresowanie Kubą wynika właśnie z tego rodzaju imperialistycznej nostalgii, jak wyjaśnia Thomas Carter:

W ideologicznie skonstruowanym świecie ciągłych zmian, hipotetycznie statyczne społeczeństwa, takie jak państwa komunistyczne, stają się punktami odniesienia do definiowania obecnej nowoczesnej tożsamości. „My” waloryzujemy innowacyjność, a potem tęsknimy za bardziej stabilnymi światami (...) kiedy tak zwane procesy modernizacyjne destabilizują społeczeństwa, agenci takiej zmiany doświadczają przemian zachodzących w innych kulturach, tak jakby były [ich] osobistymi stratami (2007: 136).

${ }^{6}$ Dane pochodzą z Kubańskiego Narodowego Biura Statystyki i Informacji: https:// hawana.msz.gov.pl/es/actualidades/por_primera_vez_polonia_entre_los_20_principales_emisores_de_turismo_a_cuba, dostęp 14.05.2018 
Choć przekazy medialne nie wykluczały klasycznego karaibskiego zestawienia słońce-morze-piasek, rozszerzono je wydatnie o zainteresowanie kulturą kubańską, zwracając w ten sposób uwagę zagranicznych gości na poszczególne elementy dziedzictwa materialnego i niematerialnego i kładąc silny nacisk na jego wartość ekonomiczną. W ten sposób taniec i pokazy taneczne, ale także aktywne uczestnictwo w lekcjach tańca, warsztaty, imprezy i koncerty, stały się istotną częścią turystyki kulturowej. Wyobrażenie podsyca wrażenia turystyczne przed przybyciem do miejsca docelowego i w dużym stopniu kształtuje dokonywane wybory. Jak podkreśla John Urry:

Oczekiwanie jest konstruowane i podtrzymywane poprzez różnorodne praktyki niezwiązane z podróżą, takie jak film, gazety, telewizja, czasopisma, płyty i nagrania wideo, które budują spojrzenie turysty. Praktyki takie dostarczają znaków, w odniesieniu do których rozumiane są doświadczenia wakacyjne, tak by to, co jest widziane, interpretowane było w kategoriach tych wcześniej określonych kategorii (1995: 132).

Oficjalna kampania promocyjna stworzona przez kubańskie Ministerstwo Turystyki, Auténtica Cuba, także opiera się na zestawie najczęściej kojarzonych z wyspą symboli. Obiecuje niezapomniane przeżycia na słonecznych plażach, gdzie turyści mogą odpocząć, sącząc mojito czy daiquiri, posmakować prawdziwych kubańskich cygar, odkrywać bogactwo kulturowe poprzez zwiedzanie kraju starym amerykańskim samochodem, a także uczestniczyć w wydarzeniach muzycznych i tanecznych. Warto zwrócić uwagę na paradoks strategii promocyjnej rewolucyjnego rządu: od momentu ponownego otwarcia się na międzynarodową turystykę oficjalne kampanie promocyjne odwzorowują częściowo przedrewolucyjny wizerunek zmysłowego raju. W dekadzie przed rewolucją kubańską w 1959 r. wyspa była powszechnie znana jako „burdel Karaibów” (Pattullo 1996). Szacuje się, że w samej tylko Hawanie działało aż 10 tys. pracowników seksualnych, czyniąc z Kuby egzotycznego, erotycznego, tropikalnego „Innego“ (Schwartz 1997). Obecne strategie promocyjne opierają się na podobnych elementach, podkreślając egzotykę afro-kubańskich występów tanecznych i ceremonii religijnych oraz uwodzicielską moc praktyk tanecznych. W ten sposób wzmacniają one globalne wyobrażenia karaibskiego piękna i zmysłowości (jak na przykład zrealizowane i opublikowane za zgodą kubańskiego rządu fotoreportaże „Na- 
A lo cubano: utowarowienie tańca i reprezentacje kubańskości...

tional Geographic” czy „Playboya”). Ten system reprezentacji opiera się głównie na obrazach ,autentycznego" tańca i muzyki, które w znacznym stopniu kształtują doświadczenia turystyczne. Antropologowie tańca szeroko omawiali kwestię konstrukcji „Innego” w odniesieniu do ucieleśnienia i społecznego tworzenia tożsamości, podkreślając, w jaki sposób ciało jest czasami kreowane jako „egzotyczne” lub ,zmysłowe” (Desmond 1997; Chakravorty 2004).

Wielu nie-kubańskich miłośników tańca, których spotkałam podczas moich badań, zdawało się doceniać lokalne formy taneczne i praktyki cielesne dla ich „czystego”, „trwałego” i „oryginalnego” charakteru. Zwykle wyjaśniano to bliższym związkiem z naturą, który miał pozwalać na lepsze połączenie $\mathrm{z}$,prawdziwym sobą”, oraz życiem w społeczeństwie kubańskim, którego wizerunek został skonstruowany jako zupełnie odmienny od kontekstów zachodnich, czyli miejsca pochodzenia turystów. Wyobraźnia odgrywa kluczową rolę w tym procesie, a autentyczność staje się „,sposobem wyobrażania sobie i idealizowania tego, co prawdziwe, tradycyjne i miejscowe w opozycji do mniej satysfakcjonujących cech codzienności" (Deloria 1998: 101). Innymi słowy, proces „turystyfikacji” (touristification) (Salazar 2011: 581) i turystyczny boom, który charakteryzował ostatnie lata na wyspie, wykazują ,ukryty orientalizm" (Said 1991), widoczny w sposobie przedstawiania Kuby jako zmysłowej, seksualnej, rasowo odmiennej od zachodniego świata i „zatrzymanej w czasie”. W ten sposób konstruowanie „Innego” jest oparte na egzotyzacji i na usytuowaniu poza czasem bieżącym (denial of coevalness, Fabian 1983).

W dalszych częściach tekstu omawiam dynamikę charakteryzującą dwa najbardziej popularne rodzaje tańca na tle turystyki międzynarodowej na Kubie: salsę, powszechnie kojarzony z szerszą ideą Cubanidad (kubańskości) taniec, wokół którego zbudowany został cały prywatny rynek szkół tańca, oraz rumbę, jako wyraz tradycji afro-kubańskich, poddaną oficjalnym strategiom patrymonializacji, mocno ambiwalentną ze względu na silne konotacje rasowe. Celem następnych fragmentów artykułu jest analiza utowarowienia tych tańców i procesów z nim związanych: wyobrażenia na temat kubańskości, implikacje w odniesieniu do nowo powstających praktyk związanych z pracą oraz istotna rola aspektu rasowego w postrzeganiu form tanecznych zarówno na wyspie, jak i poza nią. 


\title{
Salsa i budowanie biznesu tanecznego
}

W lutym 2018 r., krótko po tym, jak przyjechałam do Hawany, spotkałam się z Mireyą, menedżerką popularnej szkoły tańca w dzielnicy Centro Habana, jedną z moich najbliższych znajomych, z którą wielokrotnie już przeprowadzałam wywiady. Byłam zaskoczona, gdy dowiedziałam się, że jej brat, właściciel owej szkoły tańca, po wielu latach spędzonych za granicą niedawno wrócił na Kubę. Przejął kierowanie firmą, organizację zajęć, kontakty z klientami, a nadzór nad pracą instruktorów powierzył swojej matce. Mireya straciła pracę w dość skomplikowanym i trudnym momencie (przez ponad 8 miesięcy rząd nie wydawał nowych zezwoleń na pracę dla sektora prywatnego ${ }^{7}$ ) i w środku kryzysu rodzinnego. Była zmuszona, ale równocześnie gotowa, by zacząć wszystko na nowo:

\begin{abstract}
Zbudowałam mu imperium, a teraz on wrócił, by je zniszczyć, ponieważ nie ma pojęcia, jak działa ten biznes, nie było go przez cały ten czas, podczas gdy ja tu pracowałam dzień i noc. Ale skoro udało mi się raz, uda się i drugi. Kiedy zaczynałam pracę dla tej szkoły, nie mieliśmy nawet ścian. Teraz zaczynam w lepszym miejscu, w sercu Starej Hawany, i przynajmniej ściany stoją.
\end{abstract}

Mireya skorzystała ze starego zezwolenia na prowadzenie działalności gospodarczej i zarejestrowała firmę. Musiała jedynie wymienić dowód osobisty, ponieważ w świetle nowych przepisów biznes należy prowadzić pod adresem, pod którym jest się aktualnie zameldowanym. Już po około miesiącu mogła przyjąć pierwszych klientów, wykorzystała bowiem swoją rozbudowaną sieć kontaktów w świecie tańca, zatrudniła osoby do stworzenia strony internetowej i promowania szkoły w mediach społecznościowych, a także zaangażowała swoich nowo zatrudnionych nauczycieli tańca w coś, co nazwała trabajo comunitario (pracą na rzecz grupy). Polegała ona na wychodzeniu na ulice Starej Hawany, przekazywaniu turystom wizytówek i poszukiwaniu potencjalnych klientów wśród bywalców klubów nocnych.

Po kilku dniach Mireya zadzwoniła do mnie późnym wieczorem, aby opowiedzieć, że biuro podróży, z którym kiedyś współpracowała, skontaktowało się z nią ponownie i grupa turystów z USA umówiła się na lekcję

7 Państwo kubańskie ograniczyło prywatną przedsiębiorczość, blokując wnioski o legalizację prywatnych firm i wprowadzając nowe restrykcje, m.in. jedno gospodarstwo domowe będzie mogło mieć tylko jedną licencję na jeden rodzaj prywatnego biznesu. 
A lo cubano: utowarowienie tańca i reprezentacje kubańskości...

salsy następnego dnia. W jej głosie było słychać podekscytowanie-lekcja grupowa oznaczała, że w końcu zarobi trochę pieniędzy, zamiast tylko wydawać je na remont budynku nowej szkoły. Miała też nadzieję, że zmotywuje instruktorów tańca i skłoni ich do kontynuowania szkolenia i pracy dla szkoły oraz przekona, że takie możliwości pojawią się znów w przyszłości. Następnego wieczoru pojechałam do starej szkoły, którą wyjątkowo brat Mirei pozwolił wykorzystać, ponieważ siedziba nowej szkoły nie była jeszcze gotowa (ściany wymagały malowania, nie było luster, a instalacja wodna nie działała). Czekając na klientów, niektórzy z tancerzy tańczyli kizombę ${ }^{8}$, część paliła na balkonie papierosy, inni robili sobie selfie na tle białego prześcieradła z namalowanym logo i nazwą nowego ośrodka. Szkoła Mirei w tym czasie zatrudniała dwa rodzaje instruktorów tańca: bardziej doświadczonych, który pracowali już w innych szkołach, oraz takich z mniejszym doświadczeniem lub zupełnych amatorów. Mieli uczyć się tańczyć i jak uczyć tańca jednocześnie. Świeżo zatrudnieni instruktorzy nabywali dwóch nowych umiejętności - poznawali kroki partnera i partnerki, figury i kombinacje zgodnie z metodologią Mirei oraz metody nauczania klientów na wszystkich poziomach zaawansowania. Po miesiącu codziennego treningu nowi instruktorzy mieli uczestniczyć w zajęciach grupowych jako ,asystenci instruktorów", co jest powszechną praktyką na Kubie. Sprawia to również, że lekcje tańca są tak popularne - każdy klient/ka ma możliwość zatańczenia z kubańskim/ką partnerem/ką pod nadzorem jednego lub dwóch głównych instruktorów/ek prowadzących zajęcia, którzy zdecydują, jakie figury i kombinacje kroków zademonstrować. Kiedy czekaliśmy na grupę, paląc papierosa na balkonie, jeden z instruktorów powiedział mi:

Każdy może być instruktorem tańca w szkole, nie musisz udowadniać swoich umiejętności lub kwalifikacji, aby uzyskać pozwolenie na pracę. Ale wielu nauczycieli w tych szkołach pochodzi z ulicy, nie mają pojęcia, czym jest taniec, jak wyprostować nogę, jak używać ramion. Jeśli tego nie wiedzą, to jak mogą was uczyć?

Kiedy grupa w końcu przybyła, po krótkiej rozgrzewce i wprowadzeniu do rytmicznego wzorca kubańskiej salsy, zademonstrowaniu

${ }^{8}$ Taniec wywodzący się z Angoli oraz Wysp Zielonego Przylądka, zwany także ,afrykańskim tangiem“. 
podstawowych kroków, instruktorzy i klienci utworzyli ruedę ${ }^{9}$ Sala wypełniła się śmiechem i śpiewem, gdy tańczące pary wykonywały w tym samym czasie te same figury, przechodząc do następnego partnera w rytmie muzyki, na hasło prowadzącego ruedy. Liczba męskich partnerów była niewielka, więc mąż Mirei przyłączył się do lekcji, a później do ruedy, chociaż otwarcie przyznaje, że nie jest tancerzem i potrafi wykonać tylko podstawowy krok. Jak wyjaśniła później Mireya, nie po raz pierwszy wykorzystała swojego męża do lekcji grupowych, ponieważ jego znajomość kroku podstawowego wystarcza na lekcje dla początkujących. Poza tym najważniejsze dla klientów jest, by czuli się komfortowo, dobrze się bawili i zasmakowali „kubańskiego klimatu”.

Kiedy lekcja dobiegła końca, jeden z turystów tak ją skomentował:

Byli niesamowici. Są tacy weseli i świetnie tańczą. Przed przyjazdem tutaj objechaliśmy Amerykę i tam na ulicach nie ma muzyki. Tu muzyka jest wszędzie. To jest naprawdę fajne. To dopiero nasz pierwszy wieczór, a zaczęliśmy go w niesamowity sposób, naprawdę poczuliśmy kubański klimat.

Wraz z rosnącą popularnością kongresów i festiwali salsy na świecie, sytuujących taniec i muzykę pomiędzy dziedzictwem kulturowym a towarem rekreacyjnym (leisure commodity) (Pietrobruno 2009, Skinner 2007), powiększa się grono osób spoza Kuby, które poznają różne rodzaje kubańskiego tańca w trakcie zajęć i warsztatów oraz poprzez udział w imprezach tanecznych, które zazwyczaj obejmują tzw. parkiet kubański (przestrzeń dedykowaną tańcom kubańskim). Bez wątpienia salsa (terminu tego używa się w przestrzeniach turystycznych do opisania tańca znanego na Kubie, jako casino) jest gatunkiem najczęściej kojarzonym z Kubą w kulturze popularnej, a w konsekwencji jest jednym z kluczowych elementów kampanii promujących wysp, jako modny cel podróży, gdzie „młodzi i starzy tańczą razem na ulicach, dzień i noc”. Chociaż casino jest postrzegane jako taniec komercyjny, zawiera różnorodne elementy z innych gatunków, w tym z tańców afro-kubańskich i rumby. Casino nie jest poddawane żadnym formalnym zabiegom mającym na celu jego patrymonializację, ale stanowi jedną z istotnych form kubańskiego dziedzictwa niematerialnego, reprodukowanego w kraju

${ }^{9}$ Rueda de casino: sposób tańczenia salsy kubańskiej (casino). Pary poruszają się po kole, wykonując synchronicznie figury na hasło prowadzącego ruedy i przechodząc do następnego partnera. 
A lo cubano: utowarowienie tańca i reprezentacje kubańskości...

i za granicą poprzez globalne media i przemysł kulturowy zbudowany wokół tego tańca i jego reprezentacji. Casino powstało i rozwinęło się w społeczeństwie kubańskim w latach 50. XX wieku (Carbonero 2006, Borges, Sardiñas 2012), a następnie rozpowszechniło na całym świecie jako egzemplifikacja bogatego i różnorodnego kubańskiego dziedzictwa kulturowego. Rosnąca popularność tego tańca, szeroko promowanego w szkołach tańca oraz na festiwalach i kongresach salsy na całym świecie, doprowadziła z jednej strony do standaryzacji, a z drugiej - do procesów ulokalnienia.

Lekcje tańca, w tym przede wszystkim salsy/casino, jako okazja do doświadczenia ,innego wymiaru Kuby” pojawiły się w ofercie turystycznej dopiero w ostatnich latach, chociaż samo doświadczenie tańca (w formie zorganizowanych zajęć/warsztatów dla turystów) nie jest niczym nowym. Niektóre z państwowych instytucji tanecznych (takich jak Conjunto Folklórico Nacional lub Compañía $\mathrm{JJ}^{10}$ ) oferowały wcześniej obcokrajowcom możliwość nauki tańców afro-kubańskich, baletu lub tańca współczesnego, zwykle podczas warsztatów w ramach programów edukacyjnych. Zwiększająca się liczba szkół i autoryzowanych nauczycieli (con licencia), którzy oferują swoje usługi głównie turystom, jest jednak zjawiskiem nowym, związanym z promowaniem pracy por cuenta propia (na własny rachunek). Kubańczycy zaangażowani w taneczny biznes podchwycili tę okazję i opracowali kompleksowe strategie dla zaspokojenia potrzeb zarówno tych turystów, którzy poszukują „,autentycznego" doświadczenia, jak i miłośników muzyki i tańca, którzy odwiedzają wyspę w celu poprawienia swoich umiejętności i poszerzenia wiedzy zdobytej poza Kubą.

W starej Hawanie na każdym kroku napotkać można jakąś szkołę tań$\mathrm{ca}$, od tych z ugruntowanym miejscem na rynku, z ciągłym zapotrzebowaniem zarówno ze strony klientów indywidualnych, jak i organizatorów wycieczek, po nowsze kursy, często oferowane w barach lub restauracjach, które teraz również reklamują się jako szkoły tańca. Często na tak zwanych imprezach salsy ${ }^{11}$ w Hawanie można zobaczyć duże grupy turystów i Kubańczyków noszących koszulki z logo szkoły i czasami z napisem ,instruktor tańca” lub „nauczyciel tańca”, rozdających wizytówki szkół osobom zainteresowanym lekcjami tańca. W ostatnich latach

${ }^{10}$ Finansowane przez państwo instytucje, mające na celu zachowanie i promocję różnych form tańca i muzyki afro-kubańskiej.

${ }^{11}$ Imprezy w klubach lub imprezy festiwalowe. 
coraz więcej szkół tańca ma w swojej ofercie usługę tzw. taxi dancer: możliwość wyjścia (za dodatkową opłatą) na imprezy taneczne lub koncerty razem $\mathrm{z}$ instruktorem tańca $\mathrm{w}$ celu rozwijania umiejętności nabytych podczas zajęć.

Pomimo trudności, których przysparza (pełna dostępność w zależności od wymagań turystów, brak możliwości zaplanowania własnych zajęć, niepewność i niestabilność pracy), trabajo por cuenta propia jest postrzegana przez wielu tancerzy i właścicieli szkół tańca jako sposób na zapewnienie sobie lepszej przyszłości w porównaniu do możliwości oferowanych przez sektor państwowy. Cena za lekcję tańca zwykle wynosi około 15 CUC (nie mniej niż 12 CUC), ale może wzrosnąć do 40 CUC za dwie godziny. W przypadku większych szkół tańca kwota ta jest dzielona między tancerza i menedżera/właściciela szkoły. Tancerze zwykle pobierają około 8-10 CUC za lekcję. Często o podjęciu nowej pracy decydują głównie kwestie finansowe - zarówno w przypadku wyszkolonych tancerzy pracujących wcześniej dla przedsiębiorstw państwowych, które zdecydowali się porzucić, aby dołączyć do bardziej dochodowego biznesu nauczania turystów, jak i dla miłośników tańca (aficionados), którzy wykorzystali okazję i zaczęli nauczać cudzoziemców, aby zapewnić sobie w miarę stabilne źródło dochodów. Wielu nauczycieli tańca, prowadzących obecnie własny taneczny biznes, pamięta swoje pierwsze spotkania z turystami (i nauczaniem tańca) jako sposób na szybki i łatwy dostęp do obcej waluty. Tak było w przypadku Nestora, który w 2018 r. obchodził dziesięciolecie istnienia swojej szkoły:

Kiedy miałem 17 lat. przyjaźniłem się z takim jinetero ${ }^{12}$, który zawsze wychodził z turystami, ale nie umiał tańczyć. Pewnego dnia powiedział, że ponieważ dobrze tańczę, przyprowadzi dla mnie kilkoro turystów, którzy będą się ode mnie uczyli. Nie chciałem, bo nie miałem pojęcia, jak to się robi, ale potem przyszedł do mnie do domu z turystami i wiesz, był jinetero, był sprytny, najpierw kazał mi coś zatańczyć, żeby widzieli, co umiem, więc zatańczyłem z matką. Turyści byli pod wielkim wrażeniem, więc przez dwie godziny po prostu kazałem im patrzeć na mnie i robić to, co ja, a na koniec dali mi 6 CUC (...) Widzisz, dla mnie turyści to praca, nic więcej. Patrzę na nich i widzę bankomat.

${ }^{12}$ Określenie jinetero odnosi się do mężczyzn proponującym turystom różne usługi (wynajem auta czy taksówki, kwatery prywatnej, zakup cygar lub usługi seksualne) w zamian za gratyfikację finansową, wyjścia do klubów lub inne prezenty. 
A lo cubano: utowarowienie tańca i reprezentacje kubańskości...

Codzienne zmagania związane $\mathrm{z}$ życiem w gospodarce opartej na podwójnej walucie uzasadniają jak najczęstsze interakcje z turystami. Często prowadzą one do wchodzenia w krótkotrwałe, wakacyjne związki, wzmacniając tym samym funkcjonujący obraz egzotycznego Innego jako bardziej namiętnego, bardziej emocjonalnego i bardziej seksualnego. Stoi to jednak w sprzeczności z budowanym zarówno przez samych tancerzy, jak i właścicieli szkół tańca wizerunkiem tancerza-profesjonalisty. Romanse z klientami bywają ryzykowne dla kariery zawodowej, mogą bowiem zrujnować lata ciężkiej pracy i znacznie zmniejszyć szanse na znalezienie nowych klientów. Napięcie między możliwością nawiązania romantycznych relacji z kursantami a potrzebą utrzymania czystego, profesjonalnego „konta” wzmacnia przekonanie samych Kubańczyków na temat tego, co motywuje turystów do uczestnictwa w lekcjach tańca. Zwykle zamiar poprawy umiejętności tanecznych kojarzony jest z innym, ukrytym celem, jak wyjaśnił Adrian, jeden z moich rozmówców:

Większość kursantek, które tu przyjeżdżają, staje się niezwykle zaborcza, jeśli chodzi o nauczyciela. Niektóre dziewczyny przychodzą tutaj, szukając romansu, nawet jeśli mają chłopaków w domu. A czasami myślą, że jeśli raz zatańczysz z nimi salsę, to już chcesz z nimi chodzić.

Nauka tańca i obrazy romansu i zmysłowości, tworzone i komunikowane za pośrednictwem pokazów tanecznych, często prowadzą do elastycznego rozumienia relacji instruktor - klient i emocjonalnego zaangażowania po obu stronach. Temat krótkich, wakacyjnych romansów staje się kluczem do konstruowania i konsumowania odmienności, wpisany w ,złożony wzorzec zachowań hedonistycznych, z których większość pojawia się w wyobraźni konsumenta" (Campbell 1987: 89). W ten sposób taniec prowadzi do konstrukcji Innego, wyobrażonego jako bardziej namiętny, bardziej emocjonalny i bardziej atrakcyjny seksualnie (Pruitt, LaFont 1995). Powstające związki są często postrzegane jako czysto seksualne - zazwyczaj między kobietami pochodzenia Afro-Kubańskiego a turystami (por. Fusco 1998) lub też romantyczne, pozbawione konotacji ekonomicznych (Fernandez 1999). Jeśli chodzi o związki Kubańczyków z turystkami, zwykle są określane jako „romantyczne zaangażowanie" - chociaż nie wykluczają istotnego elementu ekonomicznego - i relacje o nich wzmacniają seksualne fantazje, które przyciągają kobiety na Karaiby (Kempadoo 2004, Simoni 2015). 
Podczas gdy instruktorzy/instruktorki wydają się bardziej elastyczni i swobodni w nawiązywaniu relacji towarzyskich z klientami/klientkami, właściciele szkół tańca są bardziej rygorystyczni. Wolą zatrudniać „profesjonalnych tancerzy”, wykształconych w uznanych instytucjach akademickich, które gwarantują odpowiednie przygotowanie artystyczne, dogłębne zrozumienie i znajomość nauczanych tańców. Ma to również tworzyć bezpieczną strefę interakcji, jak wyjaśnił mi jeden z hawańskich instruktorów:

Czasami wychodzę z grupami i zawsze mówię im, że nie obchodzi mnie, czy chcą tańczyć z kimś innym. To jest w porządku, ale jeśli chcesz wyjść z imprezy z jakimś facetem, musisz dać mi znać. Często dziewczęta nie rozumieją, że faceci mają inne intencje, że chcą pieniędzy lub czasem po prostu chcą pobyć z kobietą z zagranicy. Zawsze jest różnica między te amo i me gustas. Me gustas prawie zawsze znaczy „lubię twoje pieniądze”, ,„podoba mi się twój telefon”... Niektórzy faceci chodzą na tańce z takim właśnie celem, znalezienia dziewczyny, czasem do tańca, czasem do związku, czasem na jedną noc.

W ten sposób biznes taneczny stara się tworzyć przestrzeń bezpieczną dla turystów, gdzie logo i nazwa szkoły mają zapewniać o tym, że bierze ona odpowiedzialność nie tylko za jakość nauczania, ale także za bezpieczeństwo turysty. $Z$ drugiej strony, dla wielu turystów taniec jest ucieleśnieniem samej istoty „kubańskiego ducha”. Ten rodzaj dyskursu wykorzystuje „retorykę karaibskiego ciała” (Scher 2011), rozumianą jako ogólna pogoda ducha, beztroska i zmysłowość; podkreśla opozycję między tym, co uważa się za racjonalność świata zachodniego, a latynoamerykańską zmysłowością. Jak zauważa Juliet McMains (2013), stereotypy dotyczące mieszkańców Ameryki Łacińskiej obejmują zarówno cechy postrzegane jako pozytywne (ciepli, przyjaźni, namiętni), jak i negatywne (dramatyczni, głośni, niebezpieczni, niewykształceni, biedni) i opierają się na założeniach, że emocjonalne i fizyczne impulsy nie mogą być kontrolowane przez intelekt. Egzotyzacja karaibskich ciał wywodzi się wprost z dyskursu kolonialnego, który stworzył hiperseksualne, kolektywne wyobrażenie mieszkańców Karaibów (por. Kempadoo 2004).

Taniec nie tylko dostarcza przestrzeni do artykulacji neokolonialnych wyobrażeń, ale także tworzy wyidealizowane wersje praktyki i jej uczestników, ukierunkowane na „odzyskanie esencji” (Bendix 1997: 8). Taniec staje się egzotyczną ciekawostką, erotyczną przestrzenią seksualnych 
A lo cubano: utowarowienie tańca i reprezentacje kubańskości...

pragnień, a ostatecznie ucieczką od codziennego życia. Jednak fetyszyzacja tych elementów wyklucza inne aspekty tańca, takie jak kontekst społeczny czy twórcza ekspresja. Podejście do tańca jako zestawu kroków, kombinacji i rytmicznych wzorów upraszcza bardziej złożone wymiary tańca jako ciągle zmieniającej się ekspresji osobistej i wspólnotowej, a nawet zaprzecza im.

Na Kubie pojawienie się małych firm (szkół) prowadzących kursy tańca dla zagranicznych turystów oraz związane $\mathrm{z}$ tym zmiany w systemie pracy pokazują, jak ponadnarodowa cyrkulacja tańca kubańskiego niesie ze sobą kodyfikację i komercjalizację odrębnych kroków na potrzeby tańca konkursowego i towarzyskiego. Sposoby, w jakie uczy się o muzyce i wykształca praktyki cielesne związane z tańcem kubańskim, tworzą przestrzeń dla utowarowiania dziedzictwa kulturowego zarówno na $\mathrm{Ku}-$ bie, jak i poza nią. Równocześnie jednym z bezpośrednich efektów tych procesów jest pojawienie się silnych wyobrażeń na temat „kubańskości” ucieleśnionej w tańcu.

Jednocześnie fascynacja tańcem kubańskim (który dla wielu turystów staje się synonimem salsy) nie tylko otwiera drzwi dla alternatywnych źródeł dochodu poza sektorem państwowym, ale także tworzy kontekst pewnego rodzaju intymnych związków, uważanych przez obie strony za naturalną, płynną konsekwencję tańca. Wielu miłośników tańca uważa jednak salsę za zbyt komercyjną, dlatego też ,autentycznego" doświadczenia poszukuje w pokazach i warsztatach rumby. W następnej części analizuję procesy związane $\mathrm{z}$ patrymonializacją rumby, która pomimo formalnej ochrony ze strony państwa oraz instytucji ponadnarodowych pozostaje zmarginalizowana i mniej popularna niż salsa. W przypadku rumby ,profesjonalizm” jako narzędzie legitymizujące zostaje zastąpiony przez wyobrażenia tradycji, rodziny i kulturowej spuścizny czarnych Kubańczyków.

\section{Rumba: „autentyczne” doświadczenia i „powrót do korzeni“6}

Spośród różnych kubańskich form tanecznych pierwszą, która została poddana formalnej patrymonializacji, była tumba francesa, wpisana na listę niematerialnego dziedzictwa kulturowego UNESCO w 2008 r. w celu wzmocnienia międzypokoleniowego transferu wiedzy i umiejętności. Taniec został stworzony przez Haitańczyków pochodzenia afrykańskiego, 
którzy zostali przywiezieni na Kubę jako niewolnicy. Wykonywali oni wersje francuskich tańców dworskich (kontredanse, kadryle lub menuety) z towarzyszeniem bębnów (Daniel 2002). Jak podkreśla Grete Viddal, „podczas gdy oryginalne tańce towarzyskie białej plutokracji z biegiem lat wychodziły z użycia, czarne franceses przechowały własne ich wersje" (2010: 88). Dziś taniec ten wykonują jedynie tancerze skupieni w trzech towarzystwach, finansowanych przez UNESCO i rząd kubański, a ich występy są kierowane przede wszystkim do międzynarodowej publiczności. „Pokazy tych towarzystw, które w szczególny sposób ucieleśniają tradycje prowincji Oriente we wschodniej części Kuby, są widowiskami komercyjnymi sprzedawanymi turystom" (Pietrobruno 2009: 35).

Wpisana na listę UNESCO w 2016 r. rumba sytuuje się gdzieś w połowie drogi między salsą/casino (ta ostania cieszy się tak ogromną popularnością, że nie potrzebuje formalnej ochrony) a tradycyjną tumba francesa, która mogłaby zostać całkowicie zapomniana, gdyby nie działania instytucjonalne. Rumba powstała w latach 1850-1860 w prowincjach Hawana i Matanzas, w miejscach spotkań afrykańskich niewolników i ich potomków. Po zniesieniu niewolnictwa w 1886 roku ubodzy Afro-Kubańczycy w poszukiwaniu pracy migrowali do miast, gdzie dołączyli do biednych białych Kubańczyków. W tych mieszanych dzielnicach wszyscy uczestniczyli w spotkaniach towarzyskich, gdzie tańczono także rumbę (Daniel 1995). Muzyka i taniec twórczo czerpały z tradycji zarówno afrykańskich, jak i hiszpańskich, w efekcie dając początek nowemu, oryginalnemu kubańskiemu gatunkowi muzyki o specyficznym brzmieniu oraz rodzaju tańca.

Rumba miała przez cały XX wiek charakter zdecydowanie ambiwalentny, a jej miejsce w dyskursie narodowym było silnie uzależnione od bieżącej polityki państwa. Zwykle lokowała się gdzieś na marginesach oficjalnie akceptowanych ekspresji kultury, m.in. w ciągu pierwszych dziesięcioleci XX wieku występy rumby zostały zakazane przez władze. Natomiast w okresie 1920-1950 rozwinął się nowy rodzaj rumby, „oczyszczony”, przekształcony tak, by stał się bardziej akceptowalny dla miejscowej klasy wyższej oraz dla międzynarodowej publiczności. W tym nowym stylu rumby nie można było dostrzec jego folklorystycznego odpowiednika. Był to bowiem już inny taniec, pochodzący z kubańskiego danzonu i sonu, z elementami fokstrota i tanga (Moore 1997).

W ramach rewolucyjnego projektu ideologicznego twórczość folklorystyczna uzyskała uprzywilejowany status w ramach polityki kulturowej państwa jako główne źródło inspiracji dla rozwoju kultury narodowej 
A lo cubano: utowarowienie tańca i reprezentacje kubańskości...

(Perdono, Fernandez 1985: 32). Instytucjonalizacja rumby i występów afro-kubańskich przez reżim Castro została uznana za próbę wyeliminowania nierówności klasowych i rasowych. Takie dyskursywne dowartościowanie niekoniecznie przekładało się na instytucjonalne i ekonomiczne wsparcie zespołów rumbowych. Co więcej, jak zauważa Yvonne Daniel, ten pozornie egalitarny gest miał na celu zdyscyplinowanie rumby i utrzymywanie pod kontrolą „niepożądanych zachowań” często kojarzonych z uroczystościami oraz religijnymi świętami Afro-Kubańczyków (1995). Rumba, wskutek działań promocyjnych państwa i sektora turystycznego, jest coraz bardziej obecna w klubach tanecznych na Kubie oraz, coraz częściej, poza wyspą. Jednak oferowane turystom warsztaty rumby są nadal mniej liczne niż casino czy warsztaty „kubańskie”, a rumba coraz częściej pojawia się $\mathrm{w}$ ramach tych ostatnich jako dodatek, którym uczestnik może wzbogacić styl tańca casino, czyniąc go bardziej „autentycznym”. Chociaż niektóre lokale, gdzie tańczy się rumbę, zyskują na popularności, a nawet pojawiają się w przewodnikach turystycznych, dzięki czemu są dostępne dla szerszej, międzynarodowej publiczności, kubańska scena taneczna (w jej skomercjalizowanych formach) pozostaje zdominowana przez salsę. Moje badania terenowe pokazały, że funkcje i znaczenia rumby zostają w ciągu ostatnich lat przejęte przez wszechobecny reggaeton (Ana 2017a). Muzyka i taniec ten często kojarzone są z przesadą, wulgarnością i agresywnym zachowaniem (Lundgren 2011: 78-82). Z drugiej strony, gatunek ten jest interpretowany jako wyraz „kultury ulicy”, nie jest zatem wulgarny, lecz stanowi odbicie codziennej rzeczywistości mieszkańców kubańskich miast. W podobny sposób do niedawna opisywana była rumba.

Wielu Kubańczyków młodszego pokolenia, szczególnie wśród jasnoskórych nie-tancerzy, uznaje co prawda rumbę za część kubańskiego dziedzictwa kulturowego, lecz nie potrafi jej tańczyć, nie uczestniczy też w wydarzeniach związanych $\mathrm{z}$ rumbą. Jak relacjonował to jeden $\mathrm{z}$ moich rozmówców w Hawanie, z kilkuletnim doświadczeniem pracy jako instruktor tańca:

Chciałbym nauczyć się dobrze tańczyć guaguancó ${ }^{13}$. Ale nikt nie robi tego już tutaj na Kubie. Jeśli chcesz zobaczyć rumbę, trzeba iść na pokaz, ale my, kiedy idziemy na imprezę, tańczymy salsę, reggaeton, jakąś amerykańską muzykę - rumbę

${ }^{13}$ Jedna z trzech najbardziej popularnych odmian rumby kubańskiej. 
tańczy się tylko na pokazach i czasami na fiestas de los Santos (ceremoniach religijnych ${ }^{14}$. Większość młodych ludzi nawet nie wie, jak to tańczyć. Kiedyś była bardzo popularna, ale teraz całkowicie zniknęła z naszego codziennego życia.

Podczas gdy zwiększała się obecność, widoczność i popularność afro-kubańskiej muzyki i sztuki intensywnie promowanej przez instytucje państwowe - co dało podstawę do otworzenia nowych możliwości gospodarczych i przyczyniło się do większej międzynarodowej widoczności kraju - sami Afro-Kubańczycy nie skorzystali z tego boomu. Byli marginalizowani na przykład w branży turystycznej, gdzie warunek zatrudnienia stanowiła buena presencia (,dobry wygląd”), czyli kryterium czysto rasowe, dopuszczające dużą dowolność interpretacji, zwykle dokonywanych na szkodę ponad połowy ludności kubańskiej pochodzenia afrykańskiego (de la Fuente 1998).

Utowarowieniu rumby towarzyszy jej silne upolitycznienie. Rumba dostarcza ram dla narodowego obrazu własnego Kubańczyków, międzynarodowej reklamy i zachowania tradycji kulturowych. Warsztaty organizowane na Kubie reklamują historyczne tradycje kubańskie, promują współczesny wizerunek Kuby oraz wspierają jej wysiłki skierowane na wzrost wymiany międzynarodowej. Kraj otrzymuje zasoby bezpośrednio, dzięki uczestnictwu kursantów w warsztatach (kapitał ekonomiczny oraz symboliczny), oraz pośrednio zyskuje na stymulacji dziedzin gospodarki związanych z produkcją instrumentów, nagrań, taśm i pamiątek z warsztatów, takich jak koszulki, spódnice czy szale (Daniel 1995: 127).

Uznanie przez rząd afro-kubańskich tradycji jako części dziedzictwa narodowego doprowadziło do powstania nowych placówek kultury oraz stworzyło nowe możliwości finansowe dla zespołów folklorystycznych, które jednak nie uzyskują takiego samego poziomu dochodów, stałej promocji czy popularności wśród obcokrajowców jak w przypadku wykonawców salsy. Większość tancerzy rumby ma kontakt z turystami poprzez występy i lekcje prywatne. Co prawda organizowane są wydarzenia rumbowe pod auspicjami organizacji państwowych, które zapewniają pewien zysk, ale jest on nieporównywalny z tym przynoszonym przez kluby salsy. Kilkakrotnie, zwłaszcza w Hawanie, spotkałam licznych samozwańczych tancerzy i muzyków, którzy wykazywali chęć i gotowość do nauczania

${ }^{14} \mathrm{~W}$ afro-kubańskiej religii Regla de Ocha / Santeria, rytuałom towarzyszy muzyka i taniec (w tym często rumba). 
A lo cubano: utowarowienie tańca i reprezentacje kubańskości...

tradycyjnych tańców afro-kubańskich oraz oferowali swoje usługi jako przewodnicy po mieście. Miejsca, w których wykonywana jest rumba, stwarzają okazję również dla innych źródeł zysku, czasem tylko częściowo związanych z samym tańcem (por. Bodenheimer 2010, Knauer 2005).

Obecnie prawdopodobnie najpopularniejszym miejscem wśród turystów jest Callejon de Hamel, projekt zainicjowany w latach 90. XX w. przez kubańskiego artystę Salvadora Gonzalesa. Pierwotnym celem tego miejsca, według jego założyciela, było zaoferowanie tancerzom i muzykom afro-kubańskim przestrzeni, w której mogliby zaprezentować swoją sztukę, głównie w celu docierania do lokalnej publiczności. Jednak wąska ulica z kolorowymi, psychodelicznymi muralami i regularnymi występami rumby wkrótce stała się jednym z najbardziej popularnych miejsc w dzielnicy Centro Habana ${ }^{15}$. Obecność lokalnej publiczności podczas (głównie) niedzielnych pokazów, stwarza jedną z nielicznych okazji, by turyści mogli faktycznie zobaczyć „Kubańczyków tańczących na ulicach” i tym samym podtrzymuje aurę ,,autentyczności”.

Obecność rumby w przestrzeni publicznej nie tylko przyciąga uwagę turystów, ale według kubańskich badaczy ma duży wpływ na lokalną społeczność. Jak zauważył podczas naszej rozmowy etnograf Tato Quiñones:

Widać obecnie autobusy wypełnione turystami, które zatrzymują się właśnie tam, przy wejściu, więc natychmiast doszło do przebudowy. Gdy tylko przybyli turyści, pojawiła się specyficzna fauna: sprzedawcy tytoniu, prostytutki, kieszonkowcy, bo turyści przyciągają tego rodzaju ludzi. Ludzie z sąsiedztwa zaczęli czuć się tak, jakby byli częścią widowiska, którym mieli cieszyć się turyści.

Analiza tego konkretnego miejsca prowadzić może do interpretacji, w której rumba jest reakcją na uprzywilejowane, „białe“ przestrzenie turystyczne, tańczenie rumby tworzy miejsca, w których turyści są zaledwie tolerowani, podczas gdy centralne miejsce zajmują najbardziej zmarginalizowane grupy społeczeństwa kubańskiego (Roland 2013: 411). Wiodąca pozycja Afro-Kubańczyków w wydarzeniach związanych z rumbą jest bezdyskusyjna, jednak z moich doświadczeń w terenie wynika, że obecność turystów jest czymś, czego wielu rumberos szuka i co docenia jako pozytywny aspekt, kluczowy w kontekstach związanych z przedstawieniem rumby.

${ }^{15}$ Według mojej wiedzy Callejon de Hamel pozostaje jedynym miejscem w Hawanie, gdzie pokazy rumby są darmowe. 
Obecność turystów oraz ich zainteresowanie pokazami i występami tanecznymi niekoniecznie prowadzą do zmniejszenia autentyczności, przynajmniej nie z punktu widzenia mieszkańców dzielnicy (Comaroff, Comaroff 2009). Wielu moich rozmówców sugerowało nawet, że większa obecność tańca w miejscach przyciągających turystów zagranicznych była korzystna, nie tylko ze względu na to, że stwarzała możliwości zarobku, ale również dlatego, że wzmocniła znaczenie tańca dla lokalnej społeczności i zwracała uwagę na mniej promowane aspekty kultury kubańskiej (Ana 2017b). Lokalna społeczność rozumiała autentyczność raczej jako proces, wprowadzanie zmian i ewolucję poszczególnych elementów, o ile takie zmiany nie miały decydującego wpływu na istotę tańca ani na strukturę muzyczną. Rumba była więc tu postrzegana jako forma podlegająca nieustającym przekształceniom, łącząca oryginalny kontekst tańca (jego „pierwsze istnienie”) z jego publicznym pokazem (,drugie istnienie”), integrująca je ze sobą zamiast wykluczać (Nahachewsky 2001).

W ten sposób realia gospodarcze i nierówności społeczne wynikające z kontaktów z obcokrajowcami skutkują twórczym podejściem do zysków, utrwalając jednocześnie oczekiwania i fantazje dotyczące Kuby. Zjawisko to jest silnie naznaczone rasowo, ponieważ wielu ciemnoskórych Kubańczyków, bez dostępu do legalnych miejsc pracy w branży turystycznej, może wykorzystywać na swoją korzyść pozory „rasowej autentyczności" w przestrzeniach związanych z tańcem. To z kolei może pomóc w zrozumieniu, w jaki sposób następuje przyswajanie i adaptacja niektórych turystycznych wyobrażeń w miejscowej narracji o kubańskości (lo cubano) oraz jak ciała nabierają walorów transakcyjnych (na różne sposoby) poprzez maksymalizację kapitału kulturowego związanego z cielesnością, gdzie takie atrybuty jak „krew”, „,czarna skóra”, „korzenie”, czy „tradycja” stają się towarowymi znakami jakości.

\section{Podsumowanie}

Na przecięciu dziedzictwa kulturowego, ucieleśnionych praktyk tanecznych i turystyki powstaje przestrzeń dla negocjacji tożsamości oraz mobilności społecznej i ekonomicznej, wyartykułowanych w interakcjach kulturowych między turystami a mieszkańcami, gdzie „autentyczność” staje się narzędziem legitymizacji i uprawomocnienia doświadczenia turystycznego. 
A lo cubano: utowarowienie tańca i reprezentacje kubańskości...

Praktyki taneczne na Kubie funkcjonują również jako interfejs dla bardziej złożonych sieci alternatywnych gospodarek, które powstają jako bezpośrednie efekty tzw. rynkowego socjalizmu (Morris 2008), tworząc nowe przestrzenie, formy i źródła dochodu. Jednocześnie dostęp do obcej waluty i ciągłe kontakty z turystami zmieniają nie tylko koncepcje dotyczące pracy, etyki i profesjonalizmu, ale także osobiste wyobrażenia dotyczące stylu życia (lub wyimaginowanego sposobu życia) turystów, podróży i stabilności finansowej. Branża turystyczna i sami turyści kładą większy nacisk na wyobrażone atrybuty wyspy (zestaw kluczowych symboli, które definiują doświadczenie turystyczne przed faktycznym wydarzeniem i podczas samego doświadczenia). Kubańczycy natomiast wykorzystują elementy obowiązującego dyskursu turystycznego, by promować i rozwijać inicjatywy głęboko zakorzenione w motywacjach raczej pragmatycznych. Mają one na celu uzyskanie dostępu do obcej waluty w kraju zdominowanym przez trudności gospodarki podwójnej waluty, gdzie dostęp do legalnego zatrudnienia w branży turystycznej jest najszybszym sposobem akumulacji kapitału. W toku tego procesu podkreślane są nierówności funkcjonujące na gruncie turystyki międzynarodowej, które są tworzone i przekształcane przez praktyki społeczne.

\section{BIBLIOGRAFIA}

Ana, R. (2017a). Performing Afro-Cuban Heritage: Tradition and Transformation in the Rumba, Warszawa: Wydawnictwo CESLA UW - seria Dokumenty Robocze, $\mathrm{nr} 55$.

Ana, R. (2017b). Rumba: Heritage, Tourism and the 'Authentic' Afro-Cuban Experience. W: E. Chrysagis, P. Karampampas (red.) Collaborative Intimacies: Anthropologies of Sound and Movement, s. 163-186. Oxford: Berghahn.

Bodenheimer, R.M. (2010). Localizing Hybridity: The Politics of Place in Contemporary Cuban Rumba Performance, PhD dissertation. UC Berkeley.

Borges A., Sardiñas A. (2012). Historia del baile y la rueda de casino-salsa. La Habana: Ediciones ARTEX, SA.

Bendix, R. (1997). In Search of Authenticity - The Formation of Folklore Studies. Madison: University of Wisconsin Press.

Carbonero, G.C. (2006) De la contradanza cubana al casino. La Habana: Editorial Adagio. 
Carter, T.F. (2007). A Relaxed State of Affairs?: On Leisure, Tourism, and Cuban Identity. W: Coleman i Kohn (red.) The Discipline of Leisure: Embodying Cultures of 'Recreation', s. 127-145. New York and Oxford: Berghahn Books. Chakravorty, P. (2004). Dance, Pleasure and Indian Women as Multisensorial Subjects.VisualAnthropology, 17(1),1-17.doi.org/10.1080/08949460490273988. Comaroff, J.L., Comaroff J. (2009). Ethnicity, Inc. The University of Chicago Press. Daniel, Y. (1995). Rumba. Dance and Social Change in Contemporary Cuba. Indiana University Press.

Daniel, Y. (2002). Cuban Dance: An Orchard of Caribbean Creativity. W: S. Sloat (red.): Caribbean Dance from Abakua to Zouk: How Movement Shapes Identity, s. 23-55. Gainsville, FL: University Press of Florida.

De la Fuente, A. (1998). Recreating Racism: Race and Discrimination in Cuba's „Special Period”, Cuba Briefing Paper, no. 18. Georgetown University.

Deloria, P. (1998). Playing Indian. New Haven, Connecticut: Yale University Press.

Desmond J. (1997). Meaning in Motion: New Cultural Studies of Dance. Durham, NC: Duke University Press.

Espino, M.D. (1993). Tourism in Cuba: A Development Strategy for the 1990s?. Cuban Studies, 23, 49-69.

Fabian J. (1983). Time and the Other: How Anthropology Makes Its Object. New York: Columbia University Press.

Fernandez, N. (1999). Back to the Future? Women, Race, and Tourism in Cuba. W: K. Kempadoo (red.): Sun, Sex and Gold: Tourism and Sex Work in the Caribbean, s. 81-89. Boulder: Rowman and Littlefield.

Fusco, C. (1998). Hustling for Dollars. Jineterismo in Cuba. W: Kempadoo i Doezema (red.): Global Sex Workers. Rights, Resistance, and Redefinition, s. 151-166. London: Routledge.

Kempadoo, K. (2004). Sexing the Caribbean: Gender, Race, and Sexual Labor. New York and London: Routledge.

Kirshenblat-Gimblett, B. (1998). Destination Culture: Tourism, Museums and Heritage. Berkeley, CA: University of California Press.

Knauer, L.M. (2005). Translocal and Multicultural Counterpublics: Rumba and la Regla de Ocha in New York and Havana, PhD dissertation. New York University.

Lundgren, S. (2011). Heterosexual Havana. Ideals and hierarchies of gender and sexuality in contemporary Cuba. Uppsala University, Sweden

McMains, J. (2013). Hot Latin dance: ethnic identity and stereotype. W: A. Shay (red.), The Oxford handbook of dance and ethnicity, Oxford and New York: Oxford University Press. 
A lo cubano: utowarowienie tańca i reprezentacje kubańskości...

Moore, R. (1997). Nationalizing Blackness: Afrocubanismo and Artistic Revolution in Havana, 1920-1940. University of Pittsburgh Press.

Morris, E. (2008). Cuba's New Relationship with Foreign Capital: Economic Policy-Making since 1990. Journal of Latin American Studies, 40, 769-792. doi.org/10.1017/S0022216X08004756.

Nahachewsky, A. (2001). Once Again: On the Concept of "Second Existence of Folk Dance", Yearbook for Traditional Music, 33, 17-28.

Pattullo, P. (1996). Last Resorts. The Cost of Tourism in the Caribbean. London: Cassell.

Perdono M.A., Fernandez M. (1985). Para una caracterización del movimiento de artistas aficionados, Temas, 4, La Habana.

Pietrobruno, S. (2009). Cultural Research and Intangible Heritage. Culture Unbound, vol. 1, $227-247$.

Phillips, E. (2006). 'Cuentapropismo' in a Socialist State. W: M. Font (red.), Cuba: In Transition? Pathways to Renewal, Long-Term Development and Global Reintegration, s. 107-124. New York City: Bildner Center for Western Hemisphere Studies.

Roland L.K. (2013). T/Racing Belonging Through Cuban Tourism, Cultural Anthropology, vol. 28, issue 3, 396-419. doi.org/10.1111/ cuan. 12011.

Said, E. (1991). Orientalizm, przeł. W. Kalinowski. Warszawa: PIW.

Salazar, N.B. (2011). The Power of Imagination in Transnational Mobilities, Identities: Global Studies in Culture and Power, 18, 576-98. doi.org/10.1080/1070289X.2011.672859.

Scher,P.W. (2011). Heritage tourism in the Caribbean: the politics of culture after neoliberalism, Bulletin of Latin American Research, 30(1), 7-20. doi.org/10.1111/j.1470-9856.2010.00451.x.

Schwartz, R. (1997). Pleasure Island. Tourism and Temptation in Cuba. Lincoln: University of Nebraska Press.

Simoni, V. (2015). Breadwinners, sex machines and romantic lovers: entangling masculinities, moralities, and pragmatic concerns in touristic Cuba. Etnógrafica, 19(2), 389-411.

Skinner, J. (2007). The Salsa Class: A Complexity of Globalization, Cosmopolitans and Emotions. Identities, 14, 485-506.

Stoler, A.L. (1995). Race and the Education of Desire: Foucault's History of Sexuality and the Colonial Order of Things, Durham and London: Duke University Press.

Urry, J. (1995). Consuming Places. London and New York: Routledge. 
Viddal, G. (2010). Haitian migration and danced identity in eastern Cuba. W: S. Sloat (red.) Making Caribbean Dance: Continuity and Creativity in Island Cultures, s. 83-94. Gainesville, FL: University Press of Florida.

Yudice, G. (2003). The Expediency of Culture, Durham: Duke University Press. Yurchak, A. (2005). Everything Was Forever, Until It Was No More: The Last Soviet Generation, Princeton University Press. 